Mavi Atlas, 5(2)/2017: 438-457. Araştırma Makalesi | Research Article

Makale Geliş | Received: 15.08.2017

Makale Kabul | Accepted: 06.10.2017

DOI: 10.18795/gumusmaviatlas.353615

\author{
İlhan GÖK \\ Yrd. Doç. Dr. | Assist. Prof. Dr. \\ Gümüşhane Üniversitesi, Edebiyat Fakültesi, Tarih Bölümü, Gümüşhane-Türkiye \\ Gümüşhane University, Faculty of Letters, Department of History, Gümüşhane-Turkey \\ orcid.org/0000-0003-3231-9879 \\ ilhangok52@gmail.com
}

\title{
18. Yüzyılda Kandiye’nin Tamiri ve Limanın Temizliğine Dair Bazı Tespitler
}

Öz

Eski çağlardan beri birçok medeniyete beşiklik yapmış olan Girit'in, Osmanlı Devleti'nin denizcilik alanındaki gelişmesine paralel olarak 16. yüzyıldan itibaren ilgi alanına girdiğini söylemek mümkündür. 17. yüzyıla gelindiğinde ise Sultan İbrahim, Girit üzerine sefer yapmaya karar vermiștir. 1645 tarihinde Hanya'nın ele geçirilmesiyle başlayan Girit seferi, 1669 tarihinde IV. Mehmed zamanında Sadrazam Köprülü Fazıl Ahmet Paşa'nın Kandiye şehrini teslim almasıyla tamamlanabilmiștir. Girit'in fethinin tamamlanmasıyla Kandiye, Girit eyaletinin merkezi yapılmıștır. Kandiye'nin Hanya ve Resmo gibi diğer şehirlerden daha büyük bir şehir olması ve doğal bir limanının bulunması buranın önemini daha da arttırmıştı. Fethin akabinde Osmanlı Devleti Kandiye'de imar ve iskân faaliyetlerine girișmiş; kilise gibi dini yapıların camiye tahvil edilmesinin yanında, yıkılmış ve harap durumda olan binaların tamiri gündeme gelmişti. Kandiye'nin ilk tamiri fethin hemen akabinde IV. Mehmed'in emriyle Sadrazam Fazıl Ahmet Paşa tarafından yaptırılmıștır. 18. yüzyıla gelindiğinde ise şehirdeki binalar, kale duvarları ve liman kışların sert geçmesi, dalga aşındırması ve deprem gibi faktörlerden etkilenmiş ve tamire muhtaç duruma gelmiştir. Bunun üzerine Girit valisi ve Kandiye muhafizı, Hassa mimar halifesi, defterdar ve kadı eşliğinde İstanbul'dan gönderilen bir mübaşirle nerelerin tamire ihtiyaç duyduğu ve ne kadar masraf tutacağını keşif ve muayene defteri hazırlayıp İstanbul'a göndermişlerdir. Bunun üzerine Osmanlı Devleti şehrin ve limanın tamir edilmesi için Girit’te temini mümkün olmayan malzemelerin yanı sıra usta ve işçiler de göndermiştir. Burada keşif ve muayene defterleri kullanılarak Kandiye'nin 18. yüzyıl boyunca geçirdiği tamir süreci ele alınacaktır.

Anahtar Kelimeler: Kandiye, Keşif Defteri, Masraf, Tamir, Liman Temizliği.

\section{Some Detection on Repair of Kandiye and Cleaning of Hourbor in the $18^{\text {th }}$ Century}

\begin{abstract}
Crete had been a cradle for various civilization since the Ancient Times. It became a focal point for Ottoman Empire when their naval was strenghened in the $16^{\text {th }}$ century. In the $17^{\text {th }}$ century, Sultan Ibrahim had decided to make a campaign to Crete. In 1645, Crete campaign started with the capture of Chania but ended in 1669 Mehmet IV's Grand Vizier Fazıl Mustafa Pasha's success that obligated to surrender city of Heraklion. Heraklion became the capital of the Crete Province. Heraklion which was a greater city than Chania and Rethymno and has a natural harbour became more important. After the conquest Ottomans have started to public improvement and inhabiting. Place of worships like churches converted to the mosque and repairing of the wrecked buildings had become at the top of agenda. The first repairment of Heraklion had been done by Grand Vizier Fazıl Mustafa Pasha due to order Mehmed IV. In the $18^{\text {th }}$ century, buildings, ramprats and harbour had affected from cold winters, wave erosions an earthquakes and became disrepaired. Thereupon, Governor of Crete, Commander of Heraklion, Representative of the Imperial Architecture Union and (Hassa Mimar halifesi), and kadı and a beadle who came from Istanbul have determined the disrepaired places and total expenses. They prepared an examination registry (muayene defteri) and sent to the Istanbul. So that Ottomans sent some constructors, workmen, and unavaible materials to Crete. In our study, we will examine the $18^{\text {th }}$ century's reparation in Crete according to keşif (reconnaissance) and muayene (examination) registiries.
\end{abstract}

Keywords: Heraklion, Keşif Defteri (Reconnaissance Registry), Reparation, Harbour Sanitisation. 


\section{Kandiye'nin Tarihi ve Konumu}

Kandiye şehri Girit'in en büyük şehri olup verimli yapısından dolayı tarih boyunca birçok medeniyete ev sahipliği yapmıştır. Batılılar tarafından Heraklion şeklinde geçen tarihî şehrin ismi günümüze gelene kadar söyleniş ve yazılışında değişimlere uğramıştır. Kandiye, MÖ. 4000-1500 Minos Uygarlığı'nın merkezi olan Knossos yakınlarında yer almıştır. Minos Uygarlığı'ndan sonra Girit'i fetheden Araplar Kandiye şehri yakınlarına bir kale yaparak buraya Rabazulhandak ya da Handak ismini vermişler; bu isim Grek ve İtalyanca kaynaklara Kandaka/Kandika şeklinde geçmiştir. Kandiye ismi 13. yüzyıldaki Venedik kaynaklarında Candica ve Cantiga 15. yüzyılda ise Candia ve Candie şeklinde geçmektedir (Gülsoy 2001: 303).

Girit'te ilk yerleşim MÖ. 3000 ile 1400 yılları arasında Minos uygarlığını kuran Küçük Asyalılar olduğu tahmin edilmektedir. MÖ. 1400 yllından sonra Yunan şehir devletleri adayı istila ederek burada yerleştiler. Roma döneminde Girit Adası'nın korsan yatağı olması ve etrafa güvensizlik vermesi dolayısıyla MÖ. 69 yılında Romalılar adayı zapta giriştiler ve Ada MÖ. 67-66 yıllarında tamamıla Roma İmparatorluğu'nun hâkimiyetine geçti. Daha sonra Roma İmparatorluğunun Doğu ve Batı şeklinde ikiye bölünmesiyle Girit adası Makedonya eyaletinin altı vilâyetinden birini teşkil etti (Tukin 1996: 85).

Hz. Muaviye döneminden itibaren Girit'e yönelik Arap akınları başladı. I. Velid döneminde (705-715) adanın bazı mevkileri ele geçirilse de sonradan elden çıktı. Emeviler döneminde yapılan bu akınlar Abbasiler devrinde de sürdü. Girit Adası Halife Memun döneminde (813-833) tamamen fethedilerek İslam Devleti'nin sınırlarına dahil edildi. Endülüs Emevi Hükümdarı Hakem b. Hişam zamanında Kurtuba'da meydana gelen Rabaz Vakası'ndan sonra (818) Endülüs'ten sürülen binlerce kişinin bir bölümü bir süre İskenderiye'de kaldıktan sonra kırk parça gemiyle Girit'e gelerek adayı kademe kademe zapt etmeye başladılar. $\mathrm{Bu}$ şekilde Girit'te yerleşen Araplar burada Rabazulhandak (Kandiye) şehrini kurdular (Tukin 1996: 86). Şehir bir ylla yakın süren bir kuşatmanın ardından 961 tarihinde Bizanslılar tarafından ele geçirildi. Adanın Müslüman halkının bir bölümü burayı terk etti, önemli bir kısmı ise din değiştirmeye 
zorland1. 150 yıla yakın bir zaman geçtikten sonra yeniden kurulan Bizans idaresi sırasında ada halkı tamamen Hıristiyanlaştırıldı. VI. Haçlı seferinin ardından 1204 tarihinde Girit Adası satın alma yoluyla Venedik'e bırakıldı. Girit'e yerleşen Venedikliler adadaki hâkimiyetlerini sürdürmek için tıpkı Romalılar gibi ana vatandan bir kısım halkı getirterek burada yerleştirdiler. Sahil şehirlerinin tamamını tahkim ettikleri gibi adanın iç kısmında da müstahkem kaleler yaptılar, küçük garnizonlar kurdular (Tukin 1996: 86). Venedik idaresi altında umumi valilik haline getirilen ve dört bölgeye ayrılan Girit adasının merkezi Kandiye oldu ( Gülsoy 2001: 303).

\section{6. ve 17. Yüzyılda Osmanlı-Venedik Mücadelesi}

I. Selim zamanında Misır'ın alınması ile Osmanlı Devleti baharat yollarına da hâkim olmuştu. Ancak Akdeniz'de bir hâkimiyet kurulmadan gerek ticaret yollarının gerekse Osmanlı sahillerinin güvenliği tam anlamıyla sağlanmamış olacaktı. 16. ve 17. yüzyıllarda Malta ve Girit gibi adalardaki korsan faaliyetlerinin Osmanlı aleyhine çalışması Akdeniz'deki adaların alınmasını zorunlu hale getirmiştir (Aydın 2016: 4). 1522'de Rodos, 1568'de Sakız ve 1571'de Kıbrıs alınmıştı. 1571 tarihinde yapılan İnebahtı Savaşı'ndan sonra Osmanlı ile Venedik arasında bir dostluk kurulmuş ve 1573 tarihinde bir ahitname imzalanmıştı ve Osmanlı Devleti ile Venedik arasında kurulan barış birkaç problem dişında 1645'e kadar devam etti (Gülsoy 2004: 21).

1641 yılına gelindiğinde ise Sultan İbrahim'in Darüssaade ağalarından Sünbül Ağa ile Mısır Kadısı Bursalı Mehmed Ağa ve maiyetindeki köle ve cariyeleri ve kıymetli eşyaları Mısır'a götüren kalyon, Malta korsanları tarafından saldırıya uğradı (Aydın 2016: 9). Gemiyi ve içinde bulunanları esir alan Malta korsanları Venediklilerin elinde bulunan Hanya limanına demirlediler. Burada bir ay kalan korsanlar elde etmiş oldukları ganimetleri sattılar. Venediklilerin Malta korsanlarını himaye etmesi Osmanlı cephesinde tepkiyle karşılandı. Çok geçmeden Osmanlı Devleti, Venedik üzerine sefere çıkmaya karar verdi (Dağlı vd. 2003: 167-168). 
Osmanlılar 1645 yılında Girit'e çıkarma yaparak kısa zamanda adanın büyük bir bölümünü fethetmelerine rağmen denizden yardım alabilen ve oldukça kuvvetli surlarla tahkim edilmiş olan Kandiye Kalesi'ni alamadı. Kasım 1666 tarihinde adaya çıkan Fazıl Ahmed Paşa'nın bütün gayretlerine rağmen Kandiye bir türlü düşmüyordu. Venedik'in deniz üstünlüğü Osmanlı askerinin yiyecek ve silah ihtiyacının teminini aksatıyor, adaya başta Fransa olmak üzere çeşitli Avrupa ülkelerinden takviye askerler geliyordu. Üç yıl boyunca kaleyi azim ve sebatla muhasara eden Fazıl Ahmed Paşa’nın Fransa, Papalık ve Malta kuvvetlerini mağlup etmesi ve kuşatmayı iyice şiddetlendirmesi sonucunda Venedikliler 6 Eylül 1669 tarihinde Osmanlı ile 18 maddelik bir antlaşma yaparak 27 Eylül'de Kandiye'yi Osmanlılara teslim etti (Karaçay Türkal 2012: 541).

\section{Kandiye Şehrinin Yapıları ve Tasviri}

Kandiye Kalesi ilk olarak İspanyollar tarafından yapılmış olup kalenin ilk yapılan kısmı limanda bulunan su kulesidir. Liman ağzında bulunan bu kule deniz doldurularak kesme taştan yapılmıştır. Deniz hizasında yirmi adet top mazgalları vardı (Kahraman vd. 2003: 420). Şehir, Venediklilerin eline geçtikten sonra şehrin kenarı surlarla çevrilerek kale genişletilmiş ve şehir kale içine dâhil edilmişti. Venedikliler kaleyi tabyalı tahkimat sistemine göre bina etmişlerdi. Kale on iki adet tabyadan oluşmakta olup bu tabyalardan dokuz adedi sur duvarlarının üzerindedir. Kum Tabyası, Yassı Tabya ve Yüksek Tabya isimli tabyalar ise sur duvarının iç tarafında bulunmaktaydı. Bu tabyalar diğerlerine göre daha yüksek olup Kandiye şehrine hâkim bir konumdadır (Kahraman vd. 2003: 218). Kum Tabyası'nda seksen adet balyemez topu ve yirmi adet havan topu bulunmaktayd. Yüksek Tabya da gayet geniş ve yüksek bir tabyadır. Kuşatma esnasında Venedikliler bu tabyanın üzerine gemi direğinden yapılma ve yukarıya ip merdivenle çıkılan bir gözetleme kulesi yapmışlardı. Bu sayede Venedikliler, Akdeniz'i ve İsfakiye dağlarını gözetlerdi. Yüksek Tabya'nın içinde iki yüz adet oda bulunmaktaydı. Evliya Çelebi'nin tabiriyle içinde 5 bin adam cenk etse yerim dar demezdi. Bu tabyanın iki tarafında geniş hendekler bulunmaktaydı (Kahraman vd. 2003: 220). Kalenin Güllük tarafında, en müstahkem ve en büyük tabya 
olan Ak Tabya vardı. Ak Tabya on üç köşeli olup çevresi üç bin adımdır. Erdel'deki Varat Kalesi büyüklüğünde bir tabyadır. Beş adet kapısı vardır. Bu tabyanın altında kuşatma zamanında kazılmış büyük lağım yolları bulunmaktaydı (Kahraman vd. 2003: 222). Ak Tabya'nın sağında Bölme Tabya, solunda Öksüz Tabya ve hemen arkasında Yassı Tabya bulunuyordu. Kalenin doğu tarafı bu tabyalarla korunmaya alınmıştı. Güney taraftan asıl müstahkem tabya Yüksek Tabya’ydı. Bunun etrafında daha küçük Yarımca Tabya, Çatal Tabya, Koltuk Tabyası ve Fıçılı Tabya yer alıyordu. Kalenin batı tarafında ise, tam güneybatı köşesinde Karanlık Tabya ve ondan kuzeye doğru Hüseyin Paşa Tabyası, Panigrad Tabyası, Kızıl Tabya, Kanlı Tabya, Haçlı Tabya, Taşı tı Tabya ve Atlı Tabyalar bulunuyordu. Her tabyanın ayrı cephaneliği vardı ve bunlarda çok sayıda top bulunuyordu. Tabyaların önlerinde oldukça geniş ve derin hendekler kazılmıştı. Kalenin en müstahkem tarafları doğu ve güney taraflarıydı. Kızıl Tabya ve Kanlı Tabya'nın olduğu taraflar nispeten daha zayıftı. Fazıl Ahmed Paşa kaleye yaptığı keşif harekâtı sırasında bunu görmüş ve kalenin en zayıf yeri olan Kızıl Tabya tarafından kuşatmaya başlamıştır (Gülsoy 2004: 132-133).

Kalenin gizli kapılarla birlikte büyüklü küçüklü seksen kapısı vardı. Bu kapılardan on bir tanesi yoğun olarak kullanılmaktaydı. Bunlar; tersane gözlerinin arkasındaki Kaptan İbrahim Paşa Kapısı, Güllük Kapısı, Kethüda İbrahim Paşa'nın yeniden bina ettiği İbrahim Paşa Kapısı, Ak Tabya Kapısı, tophanenin bulunduğu taraftaki Top Kapısı, Kıble tarafındaki kemer sularının şehre geldiği yerde olan Kemer Suyu Kapısı, Panigrad Kapısı, Kızıl Tabya arkasında Veziriazam Fazıl Ahmed Paşa'nın bina ettiği Han Kapısı ve batı yönündeki Karanlık Kapı sağlam kapıdır. Tabyaların kemerleri altından gidildiği ve gayet karanlık ve sıkıntılı bir yolu olduğu için bu kapıya Karanlık Kapı denilmiştir. Ayrıca deniz kenarında Kum Kapı, Gümrük Kapısı ve Su Kulesi Kapısı yer almaktaydı. Deniz tarafındaki kapıların hepsi dişbudak ağacından yapılmış sağlam kapılardı (Kahraman vd. 2003: 219).

Kara tarafındaki sur duvarları yirmi ayak eninde fil cüssesi kadar iri taşlardan yapılmış gayet sağlam duvarlardı. Bu duvarların eni bazı yerlerde 150 ayak genişliğine ulaşmaktaydı. Kara tarafındaki surların uzunluğu dokuz bin adımdır. Yükssekliği ise bazı 
yerlerde kırk, bazı yerlerde elli ve bazı yerlerde altmış arşındır. Sur duvarlarının üzerinde köşe başlarında karavulhane denilen kârgir ve kubbeli küçük kulübeler bulunmaktaydı (Kahraman vd. 2003: 219).

Osmanlı muhasarası başladığında müstahkem bir kale-şehir durumunda olan Kandiye tabyalı tahkimat sistemine göre korunuyordu. Kuşatma döneminde ve sonrasında bizzat Kandiye'de bulunan Evliya Çelebi o zamana kadar bizzat kendi gözüyle büyüklü küçüklü üç bin yedi yüz altmış tane kale gördüğünü fakat Kandiye Kalesi gibi müstahkem bir kale görmediğini beyan eder. Evliya Çelebi, Tuna kenarındaki Yanık Kalesi ve Nemçe İmparatorluğunun merkezi olan Viyana Kalesi’nin Kandiye Kalesi'ne benzer olduğunu fakat Kandiye Kalesi'nin bunlardan daha büyük olduğunu belirtir. Yine Evliya Çelebi’nin verdiği bilgiye göre Kandiye Kalesi vaktiyle Girit'in kuzeyinde küçük bir kale olup, I. Süleyman'ın Rodos'u fethinden sonra Venedik endişeye kapılıp Girit’teki Hanya, Resmo ve Kandiye kalelerine dışardan bir kat surla daha çevirip tahkim etmiştir (Kahraman vd. 2003: 215-216). Kandiye Kalesi, Akdeniz'in kuzeye bakan tarafında üçgen şeklindedir. On iki adet tabyasıyla on iki köşe görülür fakat aslı üç köşedir. Bir köşesi doğu tarafına bakan Su Kulesi'dir. Bir köşesi batı tarafında Kızıl Tabya'dır. Diğer köşesi güneye bakan ve Yüksek Tabya'nın bulunduğu Güllük Burnu tarafıdır. Sedd-i İskender gibi taştan yapılmış sağlam ve korunaklı bir kaledir. Kalenin batı tarafındaki Kızıl Tabya tarafında sadrazam ordusuyla Kandiye müdafileri arasında azim savaşlar meydana geldiği için bu tabyaya Fethiye Tabyası da denildi (Kahraman vd. 2003: 218).

\section{Fetihten Sonraki İlk Tamirat Çalışmaları}

Kandiye üç yıla yakın süren kuşatmada top atışlarıyla harap oldu. Kandiye'nin Osmanlı idaresine geçmesinden hemen sonra Kandiye'de tamirat çalışmalarına başlandı (BOA. C.AS 1941; Karaçay Türkal 2012: 549). Kalenin ilk tamiri fetihten sonra Kandiye muhafızı tayin olunan Mısır Valisi Vezir İbrahim Paşa tarafından yapıldı (BOA. C.AS 21261). Bu dönemde sadece harap olan yapılar tamir edilmedi aynı 
zamanda İbrahim Paşa tarafından Güllük civarında bir tabya inşasına başlandı. Yine muhasara esnasında yıkılan Kızıl Tabya ve Kanlı Tabya temelinden yıkılarak yeniden inşa edildi. Daha önce Sultan İbrahim zamanında Girit'te inşa olunan İnadiyye Kalesi yıkılarak bu kalenin taşları Kandiye Kalesi tamiri için kullanıldı. Ayrıca kuşatma esnasında üç yılda kazılan hendek ve metrisler dolduruldu. Şehitler için büyük mezarlıklar yapılıp etrafı büyük hendeklerle çevrildi. (Kahraman vd. 2003: 213).

\section{Yüzyılda Şehrin Tamiri}

1669'da Kandiye'nin fethinin akabinde yapılan tamir ve inşa çalışmaları 18 . yüzyılda da devam etti. 1700-1800 arasında farklı tarihlerde Kandiye'de büyük tamir çalışmaları gündeme geldi. Binaların zamanla yıkılmaya yüz tutmalarının sebepleri iklimin sert geçmesi ve meydana gelen depremlerdi. İklimin sert geçmesi, zaman içinde binaların aşınması ve depremlerin olmasından dolayı Kandiye şehrindeki binalar ile şehri çevreleyen kalenin çeşitli yerleri ya yıkılmış ya da kullanılamayacak hale gelmişti. Osmanlı Devleti tamire muhtaç olan yerleri biran önce tamir ettirmeye ve tamiri mümkün olmayan yerlerin ise yeniden yapılması için keşif defterleri hazırlattı. Bu defterler Kandiye'nin mahallî yetkilileri ile İstanbul'dan gönderilen görevlilerin oluşturduğu heyet tarafından hazırlandı. Burada ilk önce tamiri gereken yapılar ile yıkılıp yeniden yapılması gereken binaların isimleri ve nerelerde oldukları tespit edilmiştir. Bundan sonra ise tamiratta kullanılacak malzemelerin isimleri ve miktarları ile ne kadar usta, işçi, marangoz kullanılacağı tespit edilerek tamiratın masrafı belirlenmiştir. $\mathrm{Bu}$ şekilde hazırlanan keşif defterleri İstanbul'a gönderilmiştir. Merkezdeki yöneticiler ise hazırlanan keşif defterlerine göre tamirin yapılıp yapılmadığını yakından takip etmiş ve tamirden sonra tekrar bir keşif defterinin hazırlanması ve İstanbul'a gönderilmesini istemişlerdi (BOA. D.AMH.d 25184: 2-3).

18. yüzyılda tespit edebildiğimiz kadarıyla ilk büyük tamirat 29 Zilhicce 1134/22 Ekim 1722 tarihlidir (TMSA.d 6073: 1-2). Bu tarihte Sultan İbrahim Vakfı'ndan olan caminin çatıları zaman içinde eskimiş ve minaresi de deniz tarafına 
doğru yıkılma eğilimi göstermişti. Minarenin yıkılma tehlikesi bulunması civardaki haneler için büyük bir tehlike yaratmıştı. Ayrıca muallimhane ve darülhadis binaları da harap olmuştu. Bundan dolayı mahalledeki Müslümanların iltimasıyla Kandiye Muhafızı Vezir İbrahim Paşa ve Kandiye Kadısı Hasan Efendi tarafından bir keşif defteri hazırlatıldı. Bu deftere göre Sultan İbrahim Han Camii ve minaresi için 2824 kuruş, darülhadis ve muallimhane ve etrafındaki binalar için ise 382 kuruş keşif masrafi tutmuştur. Bu yapıların tamir masrafları vakfın gücü yetmediğinden dolayı Haremeyn-i şerifeyn hazinesinden 10680 kuruş verilmesi emredilmiştir. 1722'de gündeme gelen tamirde kullanılacak malzemelerin türü ve miktarı ve fiyatına dair bir kayıt tespit edilememiştir. 1723'e gelindiğinde daha önce Defterdar Ahmet Paşa'nın yaptırmış olduğu caminin minaresi yıkılmaya yüz tuttuğundan dolayı minare yıkılıp caminin çatısından alçak tahtadan bir minare yapılmıştı. Ancak böyle büyük bir camiye ahşaptan bir minare yapılması ezan okunmasına ve ayin yapılmasına elverişli olmadığından dolayı yeniden bir minare yapılması gündeme geldi. Bunun üzerine Kandiye Muhafızı Vezir İbrahim Paşa'nın kethüdası el-Hac Hasan Ağa, vakıf mütevellisi ve caminin minaresi hakkında bilgi sahibi olanlar tarafindan 12 Muharrem 1146/25 Haziran 1733 tarihinde bir keşif defteri hazırlandı. Bu keşif defterine göre cami minaresinin yeniden yapılması için beş yüz kuruş masraf belirlendi. Ancak minarenin yapılmasına vakıf mütevellisi tarafından ruhsat verilmedi (BOA. MAD.d 1317: 4-5). Bu tarihteki keşif defterinde tamiri gerekli olan yapılardan bir diğeri Sultan İbrahim Han Camii'dir. Bu caminin zaman içinde çatısı, penceresi duvarları, döşemesi vb. yerleri harap olmuş durumdaydı. Yapılan keşfe göre 1429 kuruş 35 para $^{1}$ masraf çıkarıldı (BOA. MAD.d 1317: 5-6). Bunun yanında Sultan İbrahim Han Camii Mahallesi'ndeki mektep ve Dilgüşâ Vakfı da tamir edilmesi gereken binalardı. Bu yapıların tamiri için toplam masraf 2893 kuruş 54 para olarak hesaplandı (BOA. MAD.d 1317: 14-15).

Bunların yanında 1733 tarihinde Kandiye'nin bazı mahalleri yıkılmaya yüz tutmuş ve kullanılamayacak hale gelmişti. Bunun üzerine dönemin Girit Valisi Vezir

\footnotetext{
${ }^{1}$ 17. yüzyılın sonuna doğru yapılan düzenlemede 1 para=3 akçe, 1 kuruş=40 para olarak belirlendi. Bkz. Ali Akyıldız (2007). "Para", İstanbul: DIA, 34: 164.
} 
İbşir Mehmed Paşa (BOA. MAD.d 1106: 14) ve Girit Defterdarı el-Hac Mahmud Bey, İstanbul'dan mübaşir tayin edilen Dergah-1 âli müteferrikalarından el-Hac Ali Ağa, Hassa Mimar Halifesi Yusuf ve Kandiye'nin önde gelen kişileri tarafından mahalle mahalle gezilerek keşif defteri hazırlandı. Bu keşif defterine göre, Kandiye'de tamiri elzem olan yerler; Kandiye kalesinin sağ tarafında bulun Küçük Su Kulesi ve Büyük Su Kulesi duvarları ve iç ve dış taraftaki tabyalar, kale içinde Dergah-1 ali yeniçerileri ile yerli yeniçeri kışlakları ve mahzenleri ve cephanelikleri, hendek ve su kemerleri, Sultan Mehmed Han Camisi ve yerli yeniçeri kışlaklarındaki mescidin çatısıdır. Bu yerlerin tamiri için gerekli malzeme öncelikle Girit’ten temin edilmeye çalışıldı. Ancak Girit'te bulunmayan köknar, İznikmid topacı, Ada çubuğu, çifte omurga, çifte dolap, İznikmid çubuğu, çifte İnebol, Varna direği, çivi, tutkal, çam sakızı, çeşitli renklerde boya vb. maddeleri dönemin Hassa Mimarı Mehmed Ağa tarafından merkezden temin edilerek Kandiye'ye gönderildi (BOA. MAD.d 1106: 2-3, 16-17). Tamiratta kale neferleri, ayanlar ve varoşlarda yaşayan ahali de bedenen çalışarak yardım ettiler. 1733 tarihinde Kandiye'nin tamiri için Girit'ten temin edilen malzemelerin masrafi 8.127.996 akçe/67.733 kuruş 3 para olarak hesaplanmıştır. Bu hesaplamaya İstanbul'dan satın alınan malzemelerin masrafı dâhil değildir. İstanbul'dan satın alınan malzemelerin masrafi ise 2.830,995 akçe yani 23591,5 kuruştur (BOA. MAD.d 1106: 18).

Bu tamirden 3-4 sene sonra Kandiye'de harap olan bazı yapıların 29 Şaban 1150/ 22 Aralık 1737'de tamiri gündeme geldi. Tamirin yapılması için merkezden Girit'in mahalli görevlilerine ferman gönderildi. Gönderilen fermanda Kandiye Kalesi'nin H.1146/1733-4 senesinde sabık Girit Defterdarı Nureddin tarafindan bazı bölgelerinin tamir ettirilmesine rağmen 3-4 seneden beri şehrin bazı bölgelerinin acil tamir ettirilmesi gerektiği ve hemen tamir yapılmazsa tamir masrafların gün geçtikçe artacağından bahsedilmekteydi (BOA. D.AMH.d 24895: 2-3). Bunun üzerine 27 Zilhicce 1150/17 Nisan 1738 tarihinde Kandiye Muhafızı Vezir Ebubekir Paşa nezaretinde İstanbul'dan tamirat için gönderilen Safayi Efendi, Hassa Mimar Halifesi Yusuf Ağa, Girit Defterdarı Seyyid Mehmed ve şehrin önde gelenleri tarafından bir keşif defteri hazırlandı (BOA. D.AMH.d 24895: 2-3). Bu deftere göre Küçük Su 
Kulesi'nin doğusunda bulunan rıhtım, Küçük Su Kulesi'ndeki zabitan odası, tersane gürzleri ve kalkan duvarı, tophane mahzeninin çatısı, Numan Paşa Kasrı'nın burç duvarı, Melek İbrahim Paşa'nın yaptırdığı tabyanın bazı kısımları, Baltalar, Lazarte, Uğrun Kapısı, Ak Tabya, Yeni Kapı ve Büyük Su Kulesi’nin duvar ve hendekleri, Kızıl Kapı ve Hanya Kapısı'nın çatıları ile Sultan İbrahim Camisi'nin karşısındaki tabyanın deniz tarafındaki yerler tamir veya yeniden inşa edilmesi gerekiyordu. Bu tamir için hesaplanan masraf 807416 sağ akçe 6728kuruş 46 paradır (BOA.D.AMH.d 24895: 2-3).

1738 tarihinden sonra Kandiye şehrinin tamiri 1749 tarihinde gündeme gelmişti. Bu tarihlerde Defterdar Ahmed Paşa Mahallesi'nde bulunan ve Girit Valileri ile kap1 halkının ikamet ettikleri iki katlı sarayın bazı kısımları zamanla yıkılmış ve saray içinde oturulmayacak hale gelmişti. 1749'da padişahın emri doğrultusunda sarayın tamiri için keşif defteri hazırlandı (BOA. D.BŞM.BNE.d 15910: 4-5). Buna göre; 7 Şevval 1162/20 Eylül 1749 tarihinde hazırlanan keşif defterinde Defterdar Ahmed Paşa Camii Mahallesi'ndeki Kandiye valisinin ve görevlilerinin oturduğu sarayın iç ve dış kısımlarının tamiratı için İstanbul'dan ferman gönderilmişti (BOA. D.BŞM.BNE.d 15910: 4-6). Bu fermanda sarayın tamirinin Kazım Abdurrahman Ağa mübaşeretiyle yapılması istenmiştir. Bunun üzerine İstanbul'dan keşif için gönderilen İsmail Ağa ile birlikte Kandiye Valisi Vezir Ebu'l-Hayr Bey, Defterdar Süleyman Efendi, Turnacıbaş1 Mustafa Ağa, yerli yeniçeri zabit vekili Ali Ağa, Dizdar İsmail Ağa, sağ-sol gönüllü ağaları Ali ve Halil Ağalar ile sağ-sol azap ağaları olan Abdurrahman ve Osman Ağalar gibi Kandiye'nin ileri gelen yöneticileri bir keşif defteri hazırladılar. 1749' da hazırlanan deftere göre sarayın dışındaki fevkanî oda, divanhane, tahtanî odanın dehlizi, tavan, döşeme ile dolma duvarları, kârgir hazine odası, tahtanî hamam temeli, kârgir matbah, sarayın iç kısımlarındaki oda, tavan, pencere döşeme duvar ve dehlizlerin yanı sıra hamamın da tamir edilmesi gerekmekteydi. Ayrıca sarayın dört tarafını çevreleyen duvarlar ile iç ve dış kısımlardaki yerlerin tekrar nakşedilmesi gerekmekteydi. Bu tamiratta tamire muhtaç yerlerin alanı 10856 zira' olup toplam masraf enkaz tenziliyle birlikte 3106320 akçe yani 25886 kuruştur (BOA. D.BŞM.BNE.d 15910: 4-5). 
1749'dan sonra ise 1760 ve 1762 tarihlerinde şehrin bazı yerlerinin tamir gördüğü 23 Receb 1175/17 Şubat 1762 tarihinde Kandiye Veziri ve Defterdarı Ahmed Efendi tarafından hazırlattırılan keşif defterinden anlaşılmaktadır (BOA. D.AMH.d 25150: 2). Buna göre 1760 yılında saray ile kollukhanenin bazı kısımlarının yanında Sultan Mehmed Han Camisi'nin bazı kısımlarının harap olduğu ve tamir edilmesi gerektiği Kandiye Kadısı Mehmed Salih Efendi tarafından gönderilen bir hüccetten anlaşılmaktadır. Buna göre caminin kiremit çatısı, havale camları ve hasırları ile caminin haricindeki bütün saçaklar tamire muhtaçtı. Ayrıca caminin minaresi tamamen harap olmuş, bazı taşları düşmüş ve üzerinde ezan okunamaz bir hale gelmişti. Minare caminin üzerine doğru meyilli olduğundan rüzgar ile caminin üzerine düşme ve camiyi tamamen yıkma ihtimali meydana gelmişti. Bu nedenle minarenin tamamen yıkılıp yeni baştan yapılması gerekmekteydi (BOA. C.EV 27838).

1762'de topların konduğu mahzen, Kandiye içinde akan tatlı suyun bazı mahalleri, cephanelerin kapı ve bacaları, kale duvarı üstünde bulunan mehterhane, büyük cephane çatısının bazı kısımları ile çatıdaki büyük oluk, kale kapılarından Hanya Kapıs1 ve suyolu köprüsü tamir edilmiştir (BOA. D.AMH.d 25150: 2).

1762’den 1770 tarihine kadar Osmanlı yöneticileri tarafından Kandiye'de genel bir tamir yapılmadı. 1170 tarihine gelindiğinde ise binalar zamanla yıkılmaya yüz tutmuştu. Buna ilaveten bir de deprem olması sebebiyle şehirdeki yapıların büyük bir kısmı harap olmuştu. Gerek depremin etkisi gerekse uzun süredir tamir yapılmamasından dolayı yıkılan ve eskiyen yerlerin tamir edilmesi ve yeniden yapılması gündeme geldi. Harap olan yerlerin tamiri için Şaban 1184/Kasım 1770 tarihinde Kandiye Muhafızı ve Girit Seraskeri Vezir Hüseyin Paşa nezaretinde Girit Defterdarı Osman Efendi, Kandiye Dizdarı Hüseyin Ağa, Hassa Mimar Halifesi İsmail Ağa, vilayet ayanları, ağaları ve zabitleri tarafından yeni bir keşif defteri düzenlendi. Bu deftere göre; Liman Kapısı yakınındaki eski kasaphanenin duvarı, Parmak Kapı'nın denize bakan kısımları, Sultan İbrahim Han Camisi karşısında deniz tarafında yıkılan bazı mahaller, Kızıl Tabya’nın hisar peçeleri, Liman Kapısı'ndan Büyük Kule’ye kadar olan ve yıkılmaya meyilli bulunan duvarlar ile Büyük Kule içinde bulunan karakolhane, 
Taşlı Tabya içindeki nefer odaları ile bazı mahaller, Liman Kapısı'nda yıkılan yeniçeri kışlağı ve sair mahzenler yeniden inşa ve tamir edilmesi gereken yerlerdi. Yukarıda isimleri zikredilen yerlerin tamiri için yapılan masraf 31 yük 17730 akçe/25981 kuruş 3 paradır (BOA. D.AMH.d 25184: 2-3). Bu yerlerin keşif ve muayene defterine göre tamirinin yapılıp yapılmadığının bildirilmesi için bir keşif defteri hazırlanıp İstanbul'a bildirilmesi için Hassa Mimarı Abdi tarafından tamirde görevli Hassa Mimar Halifesi İsmail'e 16 Şaban 1184/5 Aralık 1170 tarihinde bir emir gönderilmiştir (BOA. D.AMH.d 25184: 3).

1773 'te şehirdeki bazı yapıların tamiri için bir keşif defterinin hazırlandığı anlaşılmaktadır. Fakat Topkapı ve Osmanlı Arşivi’nde 1173 tarihine ait bir keşif defteri tespit edemedik. Ancak Girit Valisi İbrahim Paşa ve Girit Defterdarı Osman Efendi tarafından yaptırılan bu tamir 7375 kuruş tutmuştur (BOA. C.AS 21261).

1776'ya gelindiğinde ise Kandiye'de büyük bir tamire ihtiyaç duyuldu. 25 Cemaziyülevvel 1190/12 Temmuz 1776 tarihinde Girit Defterdarı ve Kandiye Bina Emini Mehmed Emin tarafından bir keşif defteri hazırlattırıldı (BOA. C.AS 33160; BOA. C.AS 51218). Buna göre Kandiye'deki Küçük Kule’nin aşağısında deniz tarafındaki limanın yıkılmasından dolayı 60 zira‘ ölçüsünde yeniden bir liman yapılması gündeme geldi (BOA. C.AS 33160). Ancak bu limanın yapılması için yetenekli ustaların bulunmaması ve yapıların taş ya da tuğladan yapılmamasından dolayı sık sık tamir ve yeniden inşa edilmeye ihtiyaç duyulmuştur. Limanın yanında Büyük Kule'den Kum Kapı'ya ve Küçük Kule'den kale bedenine kadar olan yerlerin beden duvarları tamir edilmesi gerekmekteydi. Tamirin Kandiye'deki imkânlarla yapılamayacağından anlaşıldığından tamir için gerekli olan çeşitli boyutlarda karaağaç tahtası, taban darağacı, tunç ve tahta makaralar, çeşitli ebatlarda halat ve çivi gibi malzemeler Hassa Mimarbaşı Hafız İbrahim tarafından İstanbul'dan satın alınarak ve liman tamiri içinde bir kalfa ile yedi amele gönderilmesi emredildi (BOA. C.AS 51218; BOA. C.AS 33160). 1776 tarihinde yapılacak tamirin masrafi 57510 kuruş olarak hesaplandı. Ancak 29 Zilhicce 1190/8 Şubat 1777 tarihli keşif defterinde keşif ve muayenesi bir sene öncesinde yapılmış olmasına rağmen tamir ve bakımının yapılmasının mümkün 
olmadığı anlaşıldı. Bundan dolayı tamirin yapılması için daha önce İstanbul'dan gönderilmesi istenen usta ve amele ile birlikte malzemelerin mimarbaşısı tarafindan satın alınıp Kandiye’ye gönderilmesi için tekrar emir gönderildi (BOA. AE.SABH.I 3576). Bunun üzerime talep edilen malzemeler ile bir usta ve yedi amele İstanbul'dan Girit'e gönderildi (BOA. C.AS 33932). 19 Zilhicce 1190/8 Şubat 1777 tarihli keşif defterine göre tamir ve bakım için toplam masraf 7843200 akçe yani 65360 kuruş olarak hesaplanmıştı (BOA. AE.SABH.I 3576). Ancak 19 Ş. 1191/22 Eylül 1777 tarihli bir belgeden, yapılan tamirin ve liman temizliğinin yeterli olmadığından Kandiye Muhafızı Vezir Mehmed Emin Paşa ve Girit Defterdarı ve Kandiye Kalesi Bina Emini Mehmed Emin'e selefi Veysi Efendi zamanında yarım kalan tamir işlerinin bitirilmesi için emir verildi (BOA. C.AS 33932).

1777'den 1783'e kadar Kandiye'de herhangi bir yerin tamiri gündeme gelmedi. 1783 tarihinde ise Kandiye Kalesi'nin beden duvarları ve top mazgallarının bazı yerleri yıkıldığından acil tamir edilmeye ihtiyaç duyuldu. Bunun üzerine Girit Seraskeri Vezir Melek Mahmud Paşa'nın emriyle tamire ihtiyaç duyulan yerler yerli yeniçeri kethüdası el-Hac Emin Ağa, Şer‘i Mahkeme Kâtibi Arif Mehmet ve baş mimar tarafından tespit edilerek 17 Şaban 1197/18 Temmuz 1783 tarihli bir keşif defteri hazırlandı. Bu keşif defterinde acil olarak tamir edilmesi gereken yerler arasında Sultan İbrahim Camisi yakınlarındaki beden duvarı derzi ve mazgallarının yanında Yahudi Mahallesi, Kum Kapı, Hendek Kapı, Taşı Yahya, Gönüllüler Tabyası, Fıçılı Tabya, Yeni Kapı'daki Bıyıklı Tabya ve Parmak Kapı'da bulunan hendek, beden duvarı, mazgal ve top kundakları vardır (BOA.D.BŞM.BNE.d 16028). 1783'te hazırlanan bu keşif defterinde tamir edilecek yerlerin uzunluk ve yükseklikleri ve ne kadar alanın tamir edilmesi gerektiği ayrıntılı olarak belirlendi. Buna göre Kandiye Kalesi’nin içinde ve dışında tamir edilecek yerlerin zira' ölçüsü üzerinden hesaplandığı görülür. Yapılması planlanan tamirde toplam uzunluk 1188 zira', boy 63 zira', en 115,5 zira' ve metre kare olarak da 3023 zira' olarak hesaplanmıştır. Ancak tamirde kullanılacak malzemelerin cinsi ve miktarı ile işçi ücretleri belirtilmemiştir. Sadece Yerapetra ve İsperlanka kaleleri için İstiye ve Resmo sancaklarından kesilen meşe ve çınar ağaçlarından 346 adet top 
kundağı ve tekerlek kullanılmıştır. Top kundağı ve tekerlek için gerekli ağaç ve bunların nakliye ve işçi ücretleri ise 4666 kuruş 21 paradır. Kandiye'nin tamiri için gerekli toplam masraf ise 174064 sağ akçedir. Bu rakam para hesabı üzerinde 58021, kuruş olarak da 1450 kuruş 21 paradır. Bu masrafa daha sonra top kundakları ve tekerlekleri için ameliye ve ahşap masrafı olarak 4666 kuruş 21 para daha ilave edilmiş böylece toplam masraf 6117 kuruş 2 para tutmuştur (BOA.D.BŞM.BNE.d 16028: 2-3).

17 Mart 1795 tarihine gelindiğinde ise Kandiye'de birçok yerin harap olması ve kullanılamaz durumda bulunmasından dolayı şehrin tamiri için bir keşif ve muayene defteri hazırlattırıldı (BOA. D.BŞM.BNE.d 16049: 2-4). Bu keşif defterinin kimler tarafından hazırlandığına dair defterde bir bilgi olmayıp sadece dönemin Kandiye kadısı ve Baş Mimar Hafız İbrahim'in isimleri yer almaktadır. 1795 tarihinde tamire muhtaç olan yapılar arasında Fatih Sultan Mehmed Han Camisi'nin çatı, duvar ve şadırvanı, Baruthane'nin çatısı ve mahzeni, Yeniçeri kışlalarının oda, duvar, pencere, baca ve çatısı, Baltalar mevkiindeki humbaracılar mahzeninin döşeme ve çatısı, Ak Tabya'nın doğu, batı ve kuzey duvarları, Hanya Kapısı yakınlarındaki Yüzbir Gedik denilen yerdeki siper duvarları, Kızıl Tabya'daki humbaracılar mahzeninin çatı ve duvarı, Dizdar ocağının çatısı ve duvarları, iç kaledeki kolluk kışlaklarının duvarları, Sultan İbrahim Camii çarşısındaki karakolhane duvarı ile bu çarşının karşısında deniz içinde bulunan duvarlar, Parmak Kapı tarafındaki deniz beden duvarları, Kızıl Tabya'daki deniz içindeki duvarlar ve Yalı Köşkü'ndeki Küçük Kule'nin deniz tarafındaki beden duvarları vardır. Bu yerlerin tamirinde kereste, ağaç, demir çivisi, kum, kireç, horasan harc1, kızıl toprak, kurşun, kuyum gibi metal levhalar, kiremit, çapa, harç iskelesi, taş ve katran kullanılmıştır. Tamirde kullanılan keresteler sütun yapımı amacıyla kullanılıp genellikle kestane, dolap, mana gibi sütunlar kullanılmıştır. Tamirde kullanılan malzemenin cinsine göre ağırlık, adet ve yük kelimeleri ile birlikte zikredilmektedir. Kum ve toprak gibi malzemeler yük ve kayık; çivi, kireç, levha gibi malzemeler kıyye; sütun, kiremit, çapa gibi malzemeler ise adet cinsinden hesaplanmıştır. Bu dönemde Kandiye'nin tamiri için gerekli meblağ tenzil edilmiş şekliyle 11494 kuruş 16 para olarak hesaplanmıştı (BOA. D.BŞM.BNE.d 16049: 4). 
1798 yılına gelindiğinde kalenin dört tarafının deniz olması ve o sene kışın şiddetli geçmesinden dolayı kalenin içinde ve dışındaki bazı kısımlar yıkılmış ve bazı binalar ise yıkılmaya mütemayil olduğundan Kandiye Muhafızı Vezir Ferhad Paşa, Kandiye kadısı, Kandiye'nin mimarbaşı, zabitan ve ayanları tarafından tamire ihtiyaç duyulan yerler tespit edilerek bir muayene ve keşif defterinin hazırlandığ anlaşılmaktadır (BOA. C.AS 36740). Kandiye Muhafızı Vezir Ferhad Paşa tarafindan İstanbul'a gönderilen tahrirattan 1798 tarihindeki tamir için 21560 kuruş masraf tutacağı belirtilerek tamir için İstanbul'dan izin talep edilmiştir. İstanbul hükümeti bunun üzerine masrafların Girit’ten temin edilerek Girit Defterdarı tarafından tamiratın yapılmasını emretmiştir (BOA. C.AS 36740). Bu tarihteki binaların yanında kale cephanesinde bulunan top kundaklarının zamanla kullanılmayacak derece de eskimiş olduğundan üç, beş ve yedi çapında altı yüz elli adet top kundağı ile birlikte kırk beş ve seksen beş çaplarında havan kundağının yapılması istenmişti (BOA. C.AS 36740).

\section{Kandiye Limanı'nın Temizliği}

Kandiye ile ilgili kaynaklara yansıyan önemli bir konu da Kandiye Limanı'nın temizlenmesi ve limanda bulunan su kulesinin tamiri meselesidir. Kandiye Limanı şehrin kuzeydoğusunda yüz adet geminin barınabileceği işlek bir limandı. Limanın biri doğuya diğeri kuzeye açılan iki kapısı vardı. Gemilerin girdiği asıl kapı doğuya açılan kapıydı. Limanda altmış kadar sütun üzerine yapılmış yirmi kemerli ve kubbeli tersane binası bulunuyordu. Tersane binasının etrafinda asker odaları vardı. Fetihten sonra buralara bir yeniçeri odası yerleştirilmişti. Limanda ayrıca büyük bir su kulesi, on beş mahzen ve bir kilise yer alıyordu (Gülsoy 2004: 236).

Kandiye Limanı zamanla kum, toprak ve taş gibi maddeler ile dolarak gemilerin giriş çıkışlarına mani olmaktaydı (BOA. C.NF 2/89). Bu nedenle liman belirli aralıklarla temizlenmekteydi. Kandiye'nin fethinden sonra uzun zamandan beri Kandiye Limanı'na donanma uğramadığından limanın temizlenmesi ihmal edilmişti. 1700'e gelindiğinde ise taş, toprak gibi maddelerle limanın dolmasından dolayı gemiler limana 
yanaşamıyorlardı. Bunun üzerine Ağustos 1700'de Kandiye Muhafızı Vezir Ali Paşa ile Hanya Muhafızı Vezir Mehmed Paşa'ya birlikte hareket ederek limanların temizlettirmesi emredildi (BOA. A.DVNS.MHM.d 111: 910). Eylül 1700 tarihine kadar liman temizlenmediği için İstanbul'dan tekrar bir emir gönderildi. Bu emirde Ali Paşa'nın yerine tayin olunan Kandiye Muhafızı Yusuf Paşa'ya limanın taş, toprak gibi malzemelerle dolduğundan gemilerin yanaşamadığı bildirilip çektiri ve forsa gemileriyle limanı temizlettirmesi istendi (BOA. A.DVNS.MHM.d 111: 1230).

1700'den 1726'ya kadar liman temizliği dolap sefinesi ve çektiriler sayesinde yapılmaktaydı. Ancak Temmuz 1726 tarihine gelindiğinde limandaki dolap sefinesi artık kullanılmayacak duruma gelmişti. Bu nedenle yeni bir dolap sefinesi inşasına ve limanın temizlenmesi için buraya dolap sefinesine ek olarak bir sal ile iki adet mükemmel çektiri gemisi tahsis edilmesine karar verildi. Ayrıca limanda bulunan su kulesinin deniz tarafı yıkılmaya yüz tuttuğundan burasının tamiri de gündeme geldi (BOA. C.BH 6226). Limanın tamiratına memur edilen Derya beylerinden Deli Mehmed Paşazade Ömer Paşa, Ekim 1726 yılında vefat ettiği için yerine Derya Beyi Mustafa Bey tayin olundu (BOA. C.BH 10237; BOA. D.AMH.d 24895: 2-3).

1738'de Kandiye Kalesi'nin tamiri için hazırlanan keşif defterinde Kandiye Limanı'nın temizlenmesinde kullanılan dolap gemisinin kullanılamaz hale gelmesinden dolayı limanın temizlenmesi için tombaz ve sallar kullanılması ve bu amaçla bir adet kayık tombaz inşa edilmesi uygun görüldü (BOA. D.AMH.d 24895: 2-3).

1776'da Kandiye'de yapılan tamir yeterli görülmediği için 1777 tarihinde Kandiye Muhafızı Vezir Mehmed Emin Paşa ve Girit Defterdarı ve Kandiye Kalesi Bina Emini Mehmed Emin tarafından bir keşif defteri hazırlattırıldı. Bu keşif defterinde şehrin tamirinin yanında limanın temizliği de gündeme geldi. Bu tarihte yapılacak tamir ve liman temizliği için ne kadar masraf gerektiği belirtilmemiş ancak masrafların Kandiye Defterdarlığı hazinesinden ödenmesi emredilmişti (BOA. C.AS 33932).

Kandiye Kalesi'nin içindeki binaların tamirinin yanı sıra Kandiye limanının temizlenmesi meselesi her zaman gündeme gelmişti. Bunlardan bir tanesi de 11 Eylül 
1784 tarihli bir belgeden anlaşılmaktadır. Buna göre sabık Kandiye muhafızı ve hâlâ Mora muhassılı olan Mehmed Paşa'nın Kandiye'deki binaları tamir ettirildiği ancak Mehmed Paşa'nın Mora'ya tayini çıkması ve başka bir takım sebeplerden dolayı limanın temizliğinin yapılamamasından bahisle 1784 tarihinden sonra bahar mevsiminde temizlenmesi emredildi. Bu temizleme işi için yaklaşık olarak 10 bin kuruş masraf ön görülmüştü. Liman temizliği için Kandiye'de temin edilemeyen malzemeler ile usta ve işçiler mimarbaşı tarafından merkezden temin edilerek gönderildi (BOA. C.AS 52335).

3 Mayıs 1791 tarihinde Esma Sultan'1n kethüdası olan Ömer Bey tarafindan sunulan bir arzuhalde Kandiye Gümrük İskelesi'nin temizlenmesinde görevli olan dolap ağası ve maiyetindeki yirmi otuz kişilik zimmî hizmetçiler temizlik işlerini yapmak yerine başka işlerle uğraştıkları anlaşılmaktadır. Limanın temizlenmesi işi aksatıldığından liman dolmuş ve tüccar gemileri limana yanaşamaz olmuşlardı. Bundan dolayı limanın acilen temizlenmesi gündeme geldi. Liman temizliğinin yapılabilmesi için masraflarının Kandiye' de yaşayan tüccarlardan karşılanacağı belirtilmişti (BOA. C.NF 2/89).

\section{Sonuç}

1645 tarihinde başlayan Girit seferi 1669'da Kandiye'nin Fazıl Ahmed Paşa tarafından fethiyle tamamland. Fetihten sonra şehirdeki kiliseler camiye dönüştürülürken kuşatma esnasında yıkılan ve zarar gören yapılar Fazıl Ahmed Paşa tarafından 1670 'te tamir ettirildi. 18. yüzyıla gelindiğinde ise şehrin içinde ve dışında bulunan yapılar gerek iklim şartlarından ve gerekse deprem gibi doğal afetlerden olumsuz etkilenmişti. 18. yüzyıl boyunca farklı zamanlarda şehirdeki binalar ile kalenin çeşitli yerlerinin tamir edilmesi ya da yıkılıp tekrar yapılması gündeme geldi. Bunun yanında limanın kum gibi maddelerle dolması sebebiyle temizlettirilmesi meselesi de ele alındı. Şehrin tamiri ve limanın temizliği için mahallî yöneticiler ile merkezden gönderilen görevliler tarafından keşif defterleri hazırlandı. Bu defterlerde tamir edilecek 
İlhan GÖK, “18. Yüzyılda Kandiye’nin Tamiri ve Limanın Temizliğine Dair Bazı Tespitler”, Mavi Atlas, 5(2)/2017: 438-457.

binaların isimleri, inşa ve temizlik esnasında kullanılacak malzemeler ve yapılacak masraflar tespit edilmiştir. Tamir esnasında çalışacak usta ve işçiler ile birlikte tamirde kullanılacak malzemelerin bir kısmı da mimarbaşı tarafından merkezden temin edilerek Kandiye'ye gönderilmiştir. Tamir bittikten sonra ise yeniden muayene defterinin hazırlanıp gönderilmesi istenmiştir. 


\section{KAYNAKÇA}

\section{Arşiv Belgeleri}

BOA. A.DVNS.MHM. d 111.

BOA. AE.SABH.I 3576.

BOA. C.AS 509-21261.

BOA. C.AS 783-33160.

BOA. C.AS 800-33932.

BOA. C.AS. 858-36740.

BOA. C.AS 1152-51218.

BOA. C.AS 1175-52335.

BOA. C.BH. 128-6226.

BOA. C.BH. 220-10237.

BOA. C.EV. 551-27838.

BOA. C.NF. 2-89.

BOA. D.AMH.d. 24895.

BOA. D.AMH.d. 25184.

BOA. D.AMH.d. 25250.

BOA. D.BŞM.BNE.d.15910.

BOA. D.BŞM.BNE.d. 16028.

BOA. D.BŞM.BNE.d. 16049.

BOA. MAD.d. 1106.

BOA. MAD.d.1317.

TMSA. d. 6073.

AKYILDIZ, Ali (2007). "Para”, İstanbul: DIA , 34: 163-166.

AYDIN, Meltem (2016). Mustafa bin Musa Tarih-i Sefer ve Feth-i Kandiye (Fazıl Ahmet Paşa'nın Girit Seferi ve Kandiye'nin Fethi 1666-1669), İstanbul: IQ Kültür Sanat Yayıncılık.

GÜLSOY, Ersin (2004). Girit'in Fethi ve Osmanlı İdaresinin Kurulmasl (16451670), İstanbul: TATAV Yayınları. 
GÜLSOY, Ersin (2001). “Kandiye”, İstanbul: DİA, 24: 302-305.

DAĞLI, Yücel ve Seyit Ali KAHRAMAN (2003). Günümüz Türkçesiyle Evliya Çelebi Seyahatnamesi: Bursa-Bolu-Trabzon-Erzurum-Azerbaycan-Kafkasya-KırımGirit, 2(1), İstanbul: Yapı Kredi Yayınları.

KAHRAMAN, Seyit Ali, DAĞLI, Yücel ve Robert DANKOFF (2003). Evliya Çelebi Seyahatnamesi, 8. Kitap, İstanbul: Yapı Kredi Yayınları.

KARAÇAY TÜRKAL, Nazire (2012). Silahdar Fındıklılı Mehmed Ă̆a Zeyl-i Fezleke (1065-22 Ca.1106/1654-7 Şubat 1695), Marmara Üniversitesi Türkiyat Araştırmaları Enstitüsü, Doktora Tezi, İstanbul.

TUKİN, Cemal (1996). "Girit", İstanbul: DİA, 14: 85-93.

UZUNÇARŞILI, İsmail Hakkı (2003). Osmanlı Tarihi, 3(1), Ankara: Türk Tarih Kurumu Basımevi. 